\title{
Analysis on Problem of the Structure of Export Commodities in China
}

\author{
ZHANG Rui \\ Jilin Business and Technology College P.R.China,130000 \\ 33388960@qq.com
}

Key words: export; commodity structure; problem

\begin{abstract}
For a long time, under the strategy of export oriented development, our country has been the export of low value-added labor-intensive products, product structure contradiction highlights. Is faced with many new challenges and new opportunities in its opening to the outside world of our country, the author understand China's current export enterprises the status of industry structure, combined with the new features and requirements of the development of foreign trade, put forward our country's foreign trade export enterprises to adapt to the new era of domestic and international economic situation, meet a challenge, seize the opportunity, effectively change the mode of foreign trade development and optimize the import and export commodity structure, reasonable suggestions, hoping to promote the foreign trade depending on the number and speed to quality and efficiency changes, the full range, multi-level, the wide field to improve the level of China's opening to the outside world.
\end{abstract}

\section{Introduction}

Commodity structure is the enterprise in a certain scope of business, according to a certain mark ,will operate the goods into a number of categories and projects, and determine the various categories and items in the total composition of the proportion of goods. Export commodity structure refers to a country in a certain period of time, with all kinds of goods export trade volume in the proportion of total exports to represent the status of various commodities in the export trade. Export commodity structure can not only reflect the distribution of resource endowment, but also reflect the true level of economic, technological and industrial development to a certain extent.

\section{Analysis on the current situation of China's export commodity structure}

labor intensive products in the export commodities. So far, most of our country's exports are still labor-intensive products, industrial added value is low. On the one hand that our country in the development of export trade, has completed the resources from the point to the type of industry to the labor oriented industry, that is, the completion of a reasonable industrial structure transformation; on the other hand also illustrates the our country in the development of international trade nowadays there are still a lot of problems, such as labor intensive products can only produce a cheap, low-end, simple product, no funds and technical backing, to complete the design and manufacture of advanced products. Therefore, to accomplish the great leap forward development of foreign trade, we must pay close attention to adjust the shift in China's export strategy, a national initiative to guide enterprises from labor-intensive industries to capital and technology intensive 
industry, so as to make the foreign trade of our country realize the rapid and sustainable development, improve the foreign trade contribution to China's economic growth value.

Export of high and new technology products increased rapidly. The obvious advantages of technology knowledge in foreign capital enterprises make the rapid development of China's science and technology industry, and greatly promote the export of high-tech products in our country. At the same time, the scale of high-tech products is expanding, the proportion of foreign enterprises entering the industry is also rising. New and high technology industries of our country in foreign advanced enterprises, driven by, their ability has also been improved, the upgrading of high-tech industry in our country to the very important role to promote the export of China's high and new technology products, technology content and added value products, the status of enterprises with foreign investment is more important. For example, the fastest growth rate and the two kinds of high-tech industries are the electronic computer industry and mobile communication industry, and the foreign investment enterprises are outstanding in the production and export. In 2015, the export of computer and mobile equipment exports ranked the top 5 enterprises are foreign investment enterprises, which can be seen in foreign investment enterprises in high-tech industries, is the leader of China's export industry.

\section{China's export commodity structure problems}

The level of manufactured goods in the export industry is relatively low. Although China's export commodity structure has been optimized, especially the proportion of manufactured goods exports have accounted for more than $90 \%$ of total exports. However, there are also a prominent issue which, that is, China's exports of manufactured goods processing grade low, shallow, industrial manufactured exports remain to textile industrial products and mechanical equipment mainly, and the western developed countries compared to the gap is huge. Developed countries, for example, are mainly manufactured in technology and capital intensive products, accounting for more than $90 \%$ of industrial products. China's industrial products and equipment in the proportion of total exports, although it has risen to about $90 \%$, but the technology, the knowledge content is relatively low, the gap is obvious. It is difficult to adjust the export commodity structure of our country because of the low grade of manufactured goods, which seriously affects the competitiveness of our country's export commodities in the international market.

The proportion of exports of labor-intensive products is too large. The proportion of the export commodity in China's capital - and technology intensive products has exceeded the proportion of labor-intensive products, but we must also see the scale of the size of the labor-intensive products is still great, capital and technology intensive products needs to be improved. With the development of the global economic integration, the international competitive advantage of low labor cost is being weakened, and the export mode of our country is still dependent on the labor-intensive products. Rely on labor intensive products export foreign markets, in today's economic environment, there are many problems. First of all, this kind of products in the international market is facing anti-dumping investigation and the blockade of trade protectionism, the foreign market has become very small. Second, labor intensive industries in developing countries around the world have also developed, and in order to export, the development of the economy. They have more cheap labor, raw materials, such industries in China is concerned, the impact is very serious, this low value-added products used to carry out the export trade is actually a loss.

The development of trade in services is lagging behind. 2006 release of "China's Service Trade Development Report 2006" pointed out that China's trade in goods ranked third in the world, 
but only seventh in the world of service trade in the world, and the long-term service trade deficit. The technology and knowledge intensive industries in the field of global service trade are still in the primary stage of development, such as finance, post and telecommunications, insurance, consulting and so on. In our country, transportation, tourism and other traditional industries as the support services need to improve their own level of catch up rapidly.

\section{Optimizing the structure of China's export commodities}

Improving the production capacity of high-tech products and promote exports. Through the analysis of foreign trade commodity structure of our country, we recognize the difference between China with developed countries export products industry structure is mainly reflected in two aspects: first, traditional industrial manufactured goods account for the proportion is much higher than high technology products. Second, the proportion of our country's low-end labor-intensive products is too high, while the developed countries in order to develop capital technology intensive products. So, we clearly recognize the problem after, and efficient use of resources, highlighting a number of key high-tech industrial projects to do, and become the important strategic products of our country in the future, at the same time, cultivate advanced talents, in the adjustment of industrial structure at the same time, the use of advanced technology, forming our unique industrial advantages, is China's export advantage gradually from labor intensive to capital and technology intensive products, the product has a higher value, higher profitability and enterprise, so as to completely change the status of our country in the international division of labor.

Adjusting the industrial structure, vigorously develop the service trade. What is the industrial structure of a country, there will be what kind of export commodity structure, the relationship between the two are inseparable. If the rational industrial structure, then the structure of export commodities will be smooth, reasonable; conversely, the optimization of the structure of export commodities can not get the support of the industrial structure, then you must be lead to the irrational structure of export commodities. Therefore, to complete the transformation of foreign trade growth mode, the optimization of export commodities structure adjustment, only to do a good job in the basic industrial restructuring will be possible. Through the adjustment of industrial structure, and gradually form a traditional industry, electromechanical industry and high-tech industry in three major industrial clusters, and the ratio of the size of the coordination control; at the same time to speed up technology content to a higher level of industrial transfer, thus completing the structure of export products of gorgeous.

In the adjustment of industrial structure, to speed up the development of service trade. We can from the following measures: to strengthen the co-ordination of the development of trade in services, establish and perfect the management system of trade in services; to strengthen exchanges with international organizations, establish and improve the statistical system for trade in services; actively promote the development of key areas of trade in services, vigorously promote cultural products, computer and information services, transportation, finance, insurance and other key export sector; study and formulate the development of service trade policies to encourage, perfect policy laws and regulations system of trade in services; to explore the law of the development of service trade, established in accordance with the requirements of the market economy, the trade in services to promote system; the implementation of the strategy of the brand of service trade, cultivate leading enterprises of trade in services.

Promoting the upgrading of industrial products. Developed countries have been on their national capital - and technology intensive industry of automation, environmental protection, energy saving as the center of technological upgrading and transformation, and some labor intensive, 
serious pollution, consumption energy and raw material industries gradually transferred to developing countries, pollution of the local environment, consumption of resources, creating great pressure for the sustainable development of the local. We are developing countries, science and technology as well as the level of knowledge and developed countries there is a considerable gap. So, with the strength, we can not catch up with the developed countries in the short term to adjust the industrial structure and speed. But we must try our best to adjust the industrial structure of our country to the mode of development of our own. In two ways: first, the level of domestic industrial products, market segmentation, the establishment of functional level basic requirements for products processing zone, according to not the foreign customers, we are able to for the first time to clarify ideas, took the corresponding product sales, to ensure that the products can satisfy the need. Secondly, increase investment is needed, such as the selection of good quality raw materials and equipment, and constantly improve their own processing capacity, processing technology, improve the production capacity of the product at the same time, to seek new breakthroughs, new product development.

\section{Conclusion}

In the era of global economic integration, the international competitiveness of industry is undoubtedly the most critical factor for the survival and development of a country, and the continuous optimization of the industrial structure is the fundamental guarantee of the international competitiveness. With China's foreign trade dependence is increasing year by year, the relationship between industrial upgrading and foreign trade model is more closely, which is concerned, the adjustment of industrial structure of foreign trade in China is particularly urgent. Only through the optimization and adjustment of the export industry and its product structure, can we win the initiative in the future foreign trade competition.

\section{Reference}

[1] Huang Xianhai, Cai Wanting, Song Huasheng. The financial crisis and the change in the quality of exports: lipstick effect or forced to raise the issue of international trade [J]. 2015 (10)119-127.

[2] Yang Lianxing, Zhang Xiumin, Yao Chengfei. Study on the effect of heterogeneity on the quality of export and export price change -- a study of the microscopic evidence from the Chinese context [J]. world economic research. 2015 (09)109-116.

[3] Zhang Jie. Financial repression, financing constraints and export product quality [J]. financial research. 2015 (06) 111-115.

[4] Li Kun Wang, Jiang. Market entry and economic growth: An Empirical Analysis of China's manufacturing industry as an example [J]. economic research. 2015 (05)09-12. 